ORIGINAL PAPER

\title{
Employment Perspectives for Romanian Medical Doctors
}

Andrei MARIN', Ioan Alexandru MIREA², Georgiana Gabriela MARIN³, Carmen GIUGLEA ${ }^{1,4}$

\begin{abstract}
Medical schools in Romania enroll a high number of students and invest in them serious amounts of money to prepare them afterwards in the residency. Once these residents become specialists, they are left to seek out jobs for themselves. However, the job offer is scarce in the public sector, even though there is a real national deficit of doctors, especially in the rural areas. For this reason, young doctors are forced to seek jobs in private practice or to go abroad. The following survey aims to see the perspectives of the students and young doctors regarding the future jobs they will have and possible solutions to correct the paradox between having too many unemployed doctors in contrast to having a poor national coverage with medical personnel.
\end{abstract}

Keywords: medical jobs, healthcare system, doctor deficit.

\section{Rezumat}

Universitățile de medicină din România înscriu anual un număr mare de studenți și investesc sume considerabile în pregătirea acestora, atât pe timpul facultății, cât și în timpul rezidențiatului. O dată ce rezidenții devin medici specialiți, aceștia trebuie să iși găsească pe cont propriu o slujbă. Cu toate acestea, posturile în sistemul de stat sunt rare chiar și în condițiile unui deficit național de medici, în special în regiunile rurale. Din acest motiv, tinerii medici se văd nevoiți să își caute un loc de muncă în privat sau în străinătate.

Chestionarul de mai jos urmărește să evidențieze perspectivele studenților și a tinerilor medici cu privire la viitorul carierei pe care aceștia cred că îl vor avea, precum și posibile soluții cu privire la corectarea paradoxului între numărul mare de medici care nu au post într-un spital public și problema acoperirii naționale a populației cu personal medical specializat.

Cuvinte cheie: posturi medici, sistem de sănătate, deficit de medici.

\footnotetext{
' Department of Plastic Surgery, "Sf. loan" Hospital, Bucharest, Romania

2 Department of Psychiatry, "Alexandru Obregia" Hospital, Bucharest, Romania

${ }^{3}$ Department of Cardiology, „Prof. Dr. CC Iliescu" Hospital, Bucharest, Romania

${ }^{4}$ "Carol Davila" University of Medicine and Pharmacy, Bucharest, Romania
}

\section{Corresponding author.} Andrei MARIN, Department of Plastic Surgery, "Sf. Ioan" Hospital, Bucharest, Romania.

E-mail:marin_dpt@yahoo.com 


\section{INTRODUCTION}

The Romania health care system prides itself with having some of the best doctors around the world. However, in Romania there is a great deficit when it comes to providing the population with health care it needs. A study from 2016 showed that while the European average was of 3.6 doctors per 1000 people, Romania was only 2.8 doctors per 1000 people (second last in Europe, with Poland having 2.8 doctors $/ 1000$ people $)^{1}$.

Even though the student/residents believe they do not have many opportunities in Romania when regarding their careers, most of the interviewed students/ residents responded they would like to stay in Romania to practice medicine according to the surveys conducted by the Multidisciplinary Society of Medical Residents (SMMR) and the Romanian Federation of Medical Students' Associations in 2016, respectively $2019^{2,3}$.

With the salary increase, the main concern for young residents is having a place to work at the end of the residency. Due to the lack of places where they could work, some residents take into consideration from early on the possibility of working in a private clinic or learning a foreign language in order to have a second plan in case they don't get a job in the public system. For this reason the medical exodus abroad continued even after the salary increase ${ }^{4}$.

\section{MATERIAL AND METHODS}

In order to evaluate the opinion of medical personnel (students, residents and consultants) regarding their future professional activity, a 13 question survey was conducted. Most of the questions had pre-formulated answers and some of them also gave the responders the possibility to share a free answer. The survey was designed as a Google document and distributed among social media groups and pages, with national coverage and 200 responders completed questionnaire.

There were 2 aspects which were taken into consideration when creating the survey. The first aspect was the general view of the (future) doctors about working in small cities in Romania and which conditions should be met in order for them to work there. The second idea of the survey was that of working abroad - in order to see how many responders are interested in leaving Romania and how many of them have actually taken action in that direction.

The survey was conducted not only for informational purposes, but rather to show the capable autho- rities how the medical professionals think about the problems regarding their future jobs and to take action accordingly.

\section{RESULTS}

As stated, there were 13 questions addressed in the survey to evaluate the future careers of current and future doctors.

The distribution among the responders shows that most of them were residents followed by students. The majority of the students were in their $5^{\text {th }}$ and $6^{\text {th }}$ year of Medical School, while the residents covered most of the specialties.

When asked about their future careers, if they would choose a residency in Romania or one abroad, the vast majority opted for Romania.

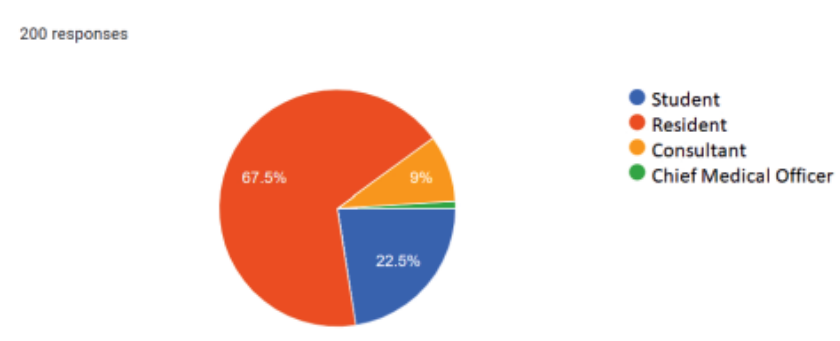

Figure 1. Distribution of the medical professionals who answered the survey.

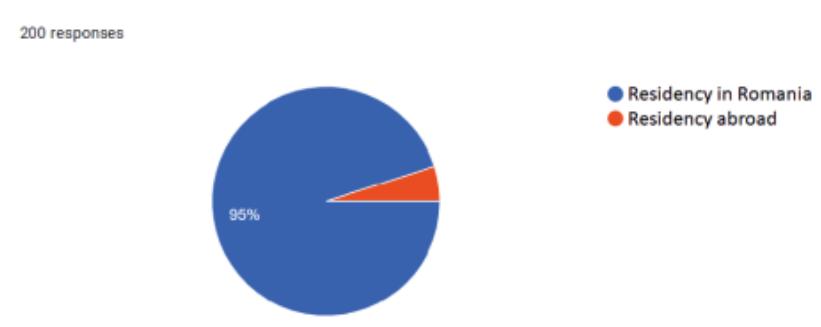

Figure 2. Graphic for residency option.

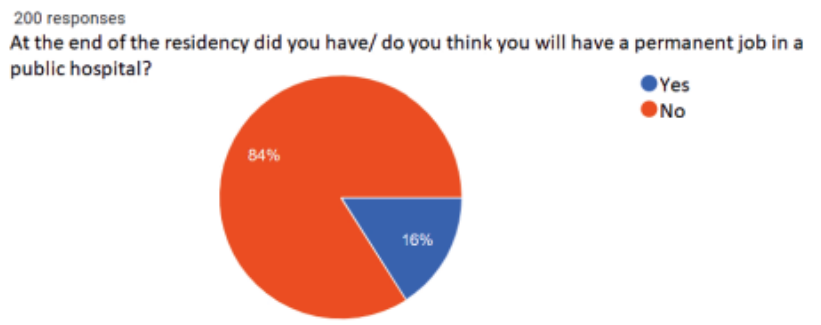

Figure 3. Graphic showing job expectancy at the end of the residency. 


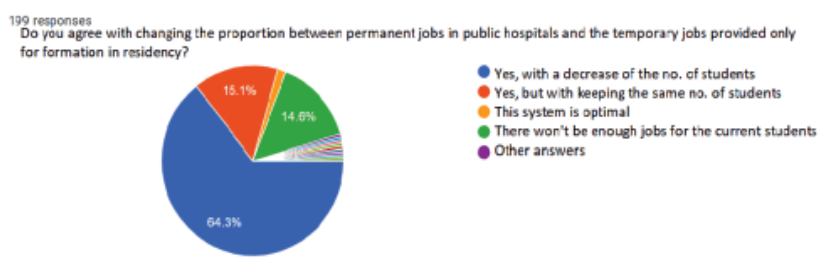

Figure 4. Graphic showing opinion regarding permanent versus temporary job for residency training.

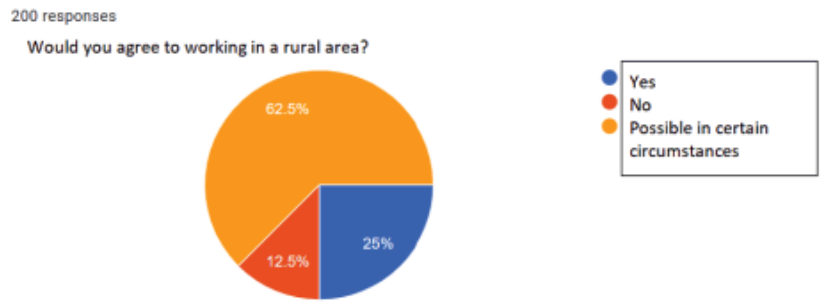

Figure 5. Graphic showing desirability of the rural area.

In Romania, a resident can choose when one takes the residency exam a permanent job in a hospital, to continue after the residency. However, these job offers are rare. Most of the people surveyed admitted to knowing about the problem of not having a job in a public hospital at the end of the residency as presented in the chart below.

Asked whether or not it would be better to increase the number of permanent jobs one can apply concomitant with the residency exam, a great proportion $(64.3 \%)$ of the responders considered this to be necessary alongside with a reduction of the number of students enrolled in the medical universities. Only $15.1 \%$ believe this to be a good idea but with keeping the current numbers of students enrolled in medical universities and $1.5 \%$ were satisfied with the current system. $14.6 \%$ believe that this would lead to a decrease

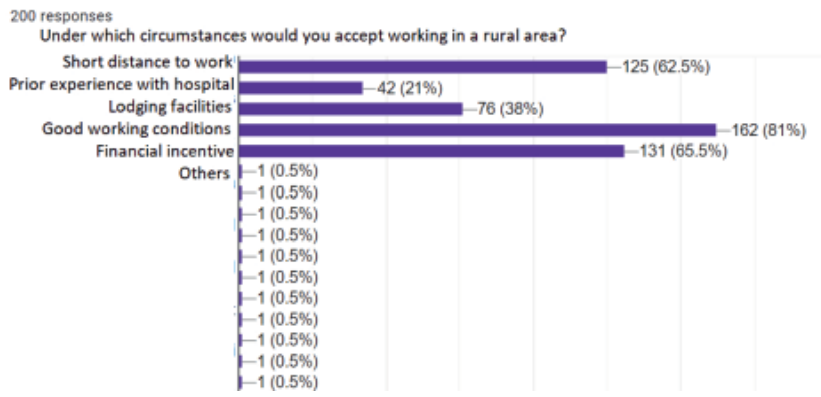

Figure 6. Graphic showing main circumstances for working in rural area.

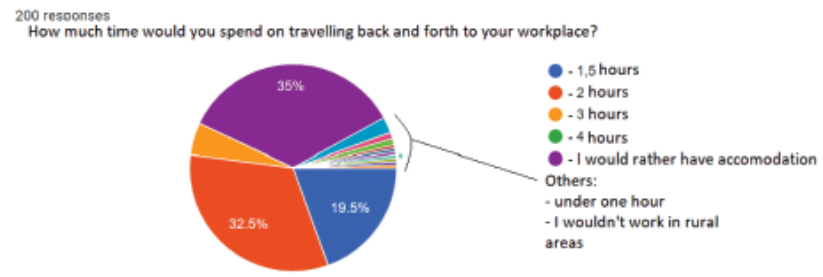

Figure 7. Graphic of accepted time for travelling to and back from work.

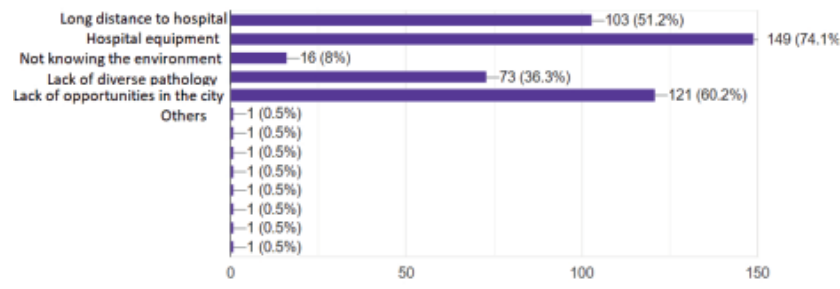

Figure 8. Reasons for evoiding small town hospitals by doctors.

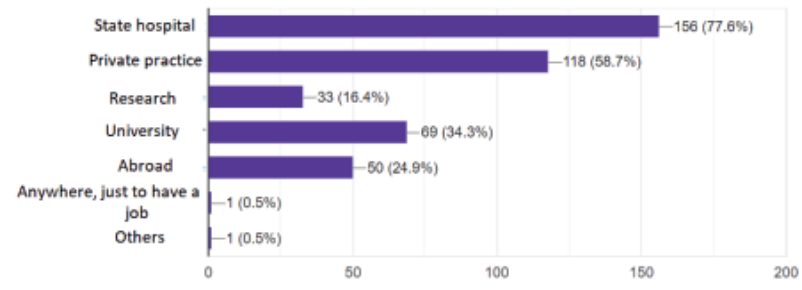

Figure 9. Job preferences after finishing the residency.

of the total number of jobs and that some of the current students could remain unemployed.

To the sensitive subject - rural jobs for medical professionals - only $12.5 \%$ rejected this possibility straightforward. 1 in 4 responders said they would work as a specialist in a rural area, while $62.5 \%$ took this possibility into consideration, provided they have the proper conditions.

When asked which are the conditions needed for them to work in rural areas, the most important aspect were in the following order - good working conditions with proper apparatus (162 respondents), while 131 required a financial stimulus (to pay for accommodation in the area or for transportation). The $3^{\text {rd }}$ most important aspect for 125 of the responders was a reasonable distance between their current location and their workplace. Other conditioned mentioned were that lodging facilities (76 responders), prior experience with that hospital, maybe during the residency (42 respon- 


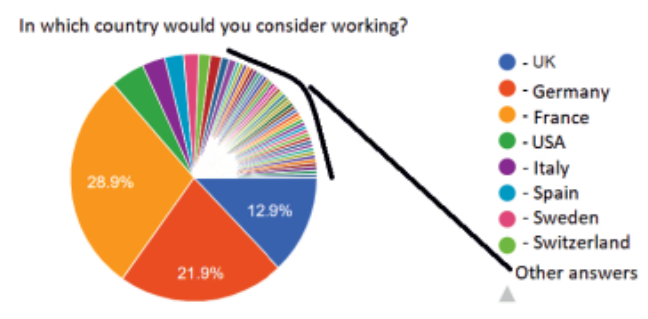

Figure 10. Graphic showing preferred countries where doctors would consider working in the future.

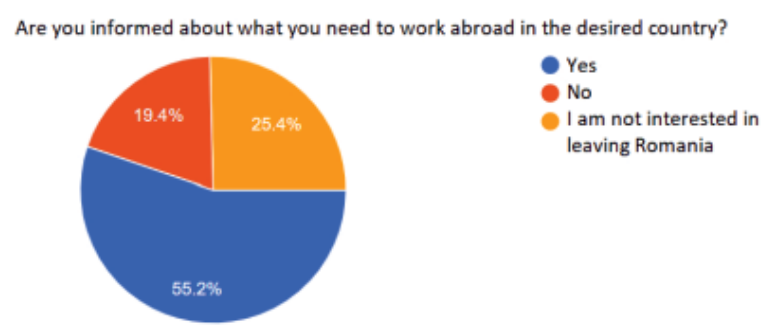

Figure 11. Graphic showing how many doctors have sought information about working abroad.

ders). Other responses mentioned good relationships with the colleagues, high standards of medical practice and a town which has cultural and educational facilities.

Out of the 200 answers, $35 \%$ responded they would prefer to have lodging facility instead of travelling daily back and forth to work, while $32.5 \%$ said they would accept to spend a maximum of 2 hours on this travel. Below is the chart with all responses.

Asked which is the main reason for not working in a hospital in the rural area, the majority answered that the equipment and unsuitable working conditions for treating patients is the biggest issue, followed by the lack of opportunities of the small town. The long distance from home and the not so varied pathology are 2 more reasons doctors stay away from small town hospitals. High level corruption, not being familiarized with the work environment and with the co-workers and lack of educational facilities were also mentioned as motives for avoiding working in rural areas.

Another question refferred to the workplace a doctor has or a future doctor believes/would like to have. As shown in the graphic below, the majority decided the state hospital to be the first choice, followed by private practice. Having many Medical Universities in Romania which train many future doctors, the $3^{\text {rd }}$ choice was having a job in the academic environment. A fair num-

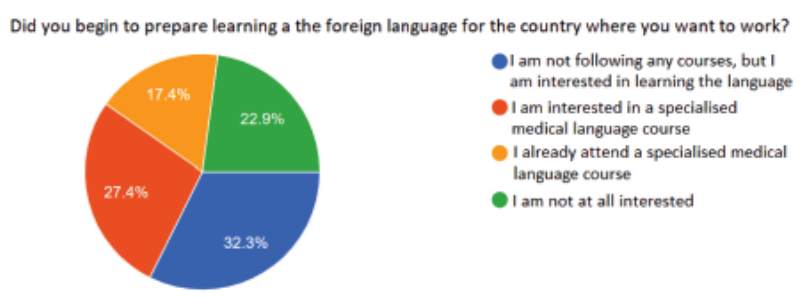

Figure 12. Chart about language preparation of the doctors.

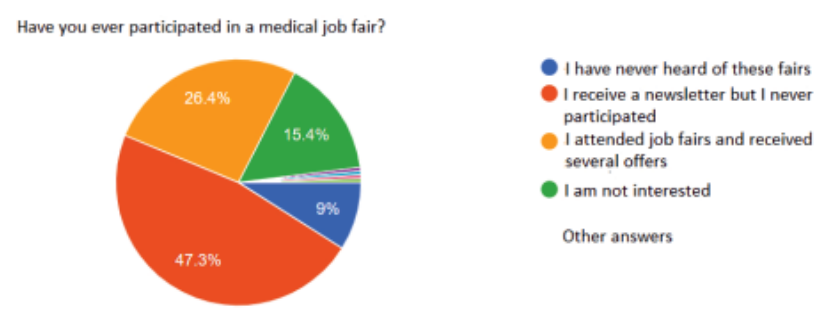

Figure 13. Graphic showing interest in medical job fairs among the responders in the survey.

ber of responders opted for working abroad, while very few believed they would follow a career in research.

The second part of the questionnaire referred to working abroad and the first question was which countries are taken into consideration by the Romanian doctors. One third of the responders said they would like to work in France, while Germany and UK were the $2^{\text {nd }}$ and $3^{\text {rd }}$ choices. USA, Italy, Spain, Sweden, Austria, Switzerland, Belgium and the Netherlands were the next countries most frequently mentioned.

The Romanian doctors also took into consideration other countries such as Canada, Australia, Finland, Denmark, Dubai, Poland, Luxemburg and even South Korea (each of these countries having only one vote). Apart from these answers, there were also some responders who said Romania is the only country they would ever work.

When asked whether or not the responders have already informed themselves about how the system works in the desired country and the bureaucratic process needed to get hired in that country, more than half said they are informed. One out of 4 doctors said they didn't want to leave Romania and only 1 of 5 responded they didn't gather information about working abroad.

After having the information needed about the bureaucracy, another key aspect is knowing the language in the country one would like to work. Asked if they 
started learning the foreign language, most of the responders replied that they were not attending any courses currently, but they would like to learn the language.

A reasonable proportion also said they would like to attend a specialized medical language course, while $17.4 \%$ answered they already attended such a course. One out of 5 responders replied they were not interested in learning any foreign language as shown in the graphic below.

The final question of the survey referred to participating at medical job fairs organized by recruiting companies which are specialized in helping hospitals abroad find medical personnel. The majority of the responders said they receive newsletters from these companies, but haven't yet participated. A smaller percentage responded they attended and received job offers. The last 2 categories replied they either were not interested in medical job fairs or have never heard of them.

\section{DISCUSSIONS}

Even though most of the responders know they will have difficulties in finding a job at the end of the residency, most of them seem to be interested in working a public hospital. Two possible explanations for this are the important salary increase in the public sector and the fact that the residency is done entirely in the public system and most of the doctors are not familiarized with private practice. Furthermore, not all specialties are suitable for private practice.

When addressing the problem of national health coverage, it seems that the doctors won't mind going to rural areas under certain conditions. With high wages, the main problem which needs to be solved by the authorities is the logistics and equipment of the hospital, as most of the responders see this to be the major impediment in working in a small town hospital. Accommodation and a not too long distance to work (meaning not too much time wasted on commuting) are also 2 crucial aspects which the authorities should address in order to have doctors in all their hospitals.

Even though the general impression is that no doc-

\section{References}

1. https://rohealthreview.ro/cel-mai-mic-numar-de-medici-dinue-raportat-la-populatie-in-romania-marea-britanie-si-polonia/

2. Andrei MARIN, Teodor Cristian BLIDARU, Georgiana Gabriela MARIN. Main Concerns in the Romanian Medical System - a Doctor's Perspective Over the Last 3 Years. Modern Medicine | 2019, Vol. 26, No. 3 tor would leave Romania provided he/she would have a stable job, with reasonable working conditions, the general opinion is that these conditions would not be met in the near future and therefore some doctors started working on backup plan - working abroad. Countries in Europe remain the first choice for doctors who want to work abroad, probably because of the proximity to Romania and because the medical diplomas are recognized inside the European Union.

Some doctors are well informed about what they need to practice medicine abroad and are studying the language. Additional help in working abroad can be offered by the headhunting companies, which facilitate the first interaction between employers all over the world and doctors who choose to work abroad.

\section{CONCLUSIONS}

The survey conducted shows the opinion of 200 doctors/future doctors regarding their job possibilities. Some choose to remain and practice medicine in Romania; others choose to prepare to work abroad.

Most of those interrogated, although concerned about not having a stable job at the end of the residency, show interest in the possibility of working in rural areas in Romania under certain conditions.

The article also reveals the main issues doctors about working in small town hospitals (lack of proper equipment they need to practice medicine, time wasted for daily commute, lack of opportunities and facilities in small towns). By progressively solving these problems by the authorities, Romania may be able to have national health coverage with well-trained specialists that can provide proper health care for their patients.

Compliance with ethics requirements: The authors declare no conflict of interest regarding this article. The authors declare that all the procedures and experiments of this study respect the ethical standards in the Helsinki Declaration of 1975, as revised in 2008(5), as well as the national law. Informed consent was obtained from all the patients included in the study.

3. https://issuu.com/teodorblidaru/docs/fasmr-raport-preliminar-rezidentiat

4. https://www.zf.ro/profesii/exodul-medicilor-a-continuat-inciuda-majorarilor-salariale-din-sanatate-1-600-de-mediciau-cerut-avize-in-2018-pentru-a-profesa-in-strainatate-17888406 . 
